\title{
Spontaneous Resolution of Chylothorax- Associated Lymphoma Treated with External Beam Radiotherapy: A Case Report and Comprehensive Review of the Literature
}

\author{
Joanna M. Laba ${ }^{1}$, Timothy K. Nguyen ${ }^{2}$, R Gabriel. Boldt ${ }^{3}$, Alexander V. Louie ${ }^{2}$ \\ 1. Radiation Oncology, Juravinski Cancer Centre, Hamilton, ON 2. Department of Radiation Oncology, \\ London Regional Cancer Program, Western University, London, Ontario, CA 3. London Health Sciences \\ Centre
}

$\square$ Corresponding author: Joanna M. Laba, joanna.laba@medportal.ca

Disclosures can be found in Additional Information at the end of the article

\section{Abstract}

Chylothorax is a rare complication of advanced lymphoma. We present the case of an 80-yearold man diagnosed with B cell lymphoma presenting with a right chylothorax secondary to a large retroperitoneal mass. His disease was not responsive to initial treatment with chemotherapy. Fractionated radiotherapy to a dose of 2,000 cGy in five fractions was delivered to the retroperitoneal mass, and the chylothorax improved significantly within days of initiation of treatment.

Categories: Radiation Oncology

Keywords: lymphoma, chylothorax, radiotherapy

\section{Introduction}

Chylothorax is a rare but serious condition whereby chyle leaks from the lymphatic system into the pleural cavity as a result of the disruption of the thoracic duct at any point along its course. The causes of chylothorax can be classified as traumatic (iatrogenic or non-iatrogenic) or non-traumatic. Malignancy is the most common cause of non-traumatic chylothorax, and lymphoma accounts for $70 \%$ of these cases [1].

Received 09/01/2015 Review began 09/08/2015 Review ended 08/22/2016 Published 08/31/2016

\section{C) Copyright 2016}

Laba et al. This is an open access article distributed under the terms of the Creative Commons Attribution License CC-BY 3.0., which permits unrestricted use, distribution, and reproduction in any medium, provided the original author and source are credited.
As there are few reports describing clinical outcomes related to this unique clinical situation, we present the case of a patient diagnosed with a massive retroperitoneal B-cell lymphoma presenting initially with a large right-sided chylothorax.

\section{Case Presentation}

An 80-year-old man presented to his family doctor with a six-week history of persistent dry cough. He was initially treated with a course of antibiotics for presumed pneumonia; however, his symptoms did not resolve. He denied any fevers, weight loss or night sweats. He did not have any pain, nausea, or vomiting. A chest X-ray done by his family physician showed a large right pleural effusion. A CT scan of the chest, abdomen, and pelvis revealed a large retroperitoneal mass measuring 12 x 17 x $29 \mathrm{~cm}$, encasing the aorta and extending centrally into the mesentery (Figure 1). 


\section{Cureus}

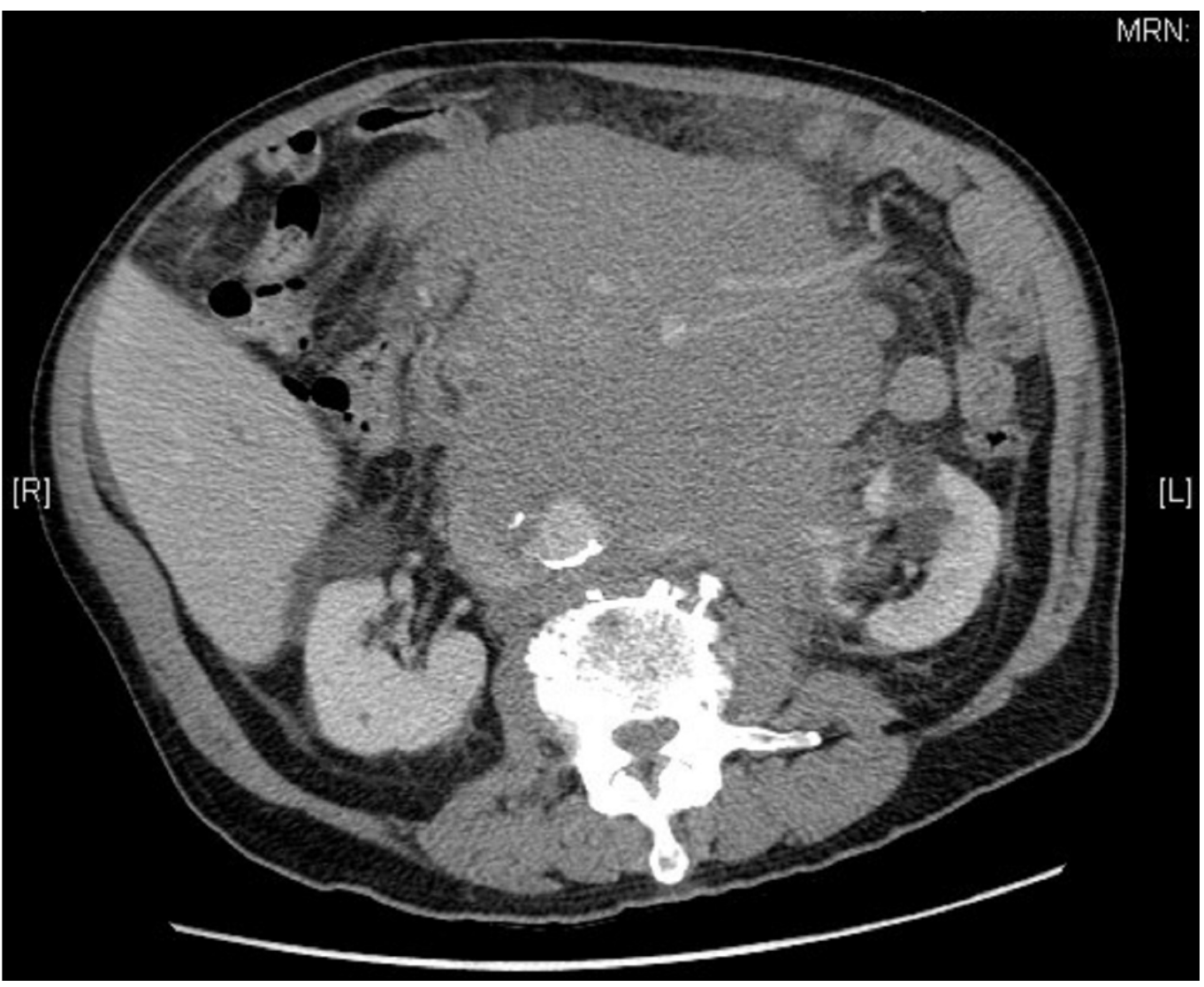

\section{FIGURE 1: Axial CT showing a large retroperitoneal mass with encasement of the aorta}

The patient was admitted to thoracic surgery for management of the pleural effusion with the insertion of a chest tube. Informed patient consent was obtained. His initial bloodwork showed significant peripheral lymphocytosis and a normal LDH. Thoracentesis demonstrated chylous pleural fluid, and cytology was consistent with small B-cell lymphoma. An ultrasound-guided core needle biopsy of the retroperitoneal mass showed diffuse lymphoid infiltrate with immunohistochemistry suggestive of chronic lymphocytic leukemia/small B-cell lymphoma.

The patient was placed on total parenteral nutrition (TPN), and his case was discussed in multidisciplinary rounds. With a chest tube in place, he was started on chemotherapy with bendamustine and rituximab. Drainage from the chest tube improved initially after the first cycle of chemotherapy from $400-500 \mathrm{~mL} /$ day to $90 \mathrm{~mL} /$ day. He was put back on a regular diet, the chest tube was removed, and he was discharged from the hospital to continue care as an outpatient.

Two weeks later, prior to his second cycle of chemotherapy, the right chylothorax reaccumulated. This was initially managed conservatively with close monitoring, and he continued with the second cycle of bendamustine and rituximab chemotherapy. The patient developed progressive worsening of his shortness of breath, and a chest X-ray demonstrated a further increase in the size of right pleural effusion. He was re-admitted to hospital and required reinsertion of a right chest tube.

A repeat CT scan of the chest, abdomen, and pelvis did not show any decrease in the size of the large retroperitoneal mass after two cycles of chemotherapy. The mass encased the aorta 


\section{Cureus}

without causing obstruction of its major branches. Radiation Oncology was consulted on weekend call by the thoracic surgery team for consideration of urgent palliative radiotherapy.

Radiation treatment was planned using onboard imaging with the patient positioned supine with arms at his sides. Treatment was started urgently. The entire retroperitoneal mass was treated using an anterior-posterior/posterior-anterior technique with $18 \mathrm{MV}$ photons to a dose of 2,000 cGy in five fractions prescribed to mid-plane. The patient was premedicated with $8 \mathrm{mg}$ of ondansetron orally one hour prior to each fraction of radiotherapy. He completed the course of radiation uneventfully and denied any side effects, such as fatigue, nausea, vomiting, or diarrhea. Drainage from the chest tube prior to radiation treatment was more than 4 liters over 24 hours. This decreased significantly to $220 \mathrm{~mL} / 24 \mathrm{hrs}$ two days after the last fraction of radiation (Table 1). With this decrease in drainage, the patient became a candidate for talc pleurodesis, which was performed three days after completion of the radiotherapy.

\begin{tabular}{|c|c|c|}
\hline & Days since admission & Drain output (mL/24 hours) \\
\hline \multirow[t]{4}{*}{ Start of RT $\rightarrow$} & 2 & 910 \\
\hline & 3 & 810 \\
\hline & 4 & 730 \\
\hline & 5 & 360 \\
\hline \multirow[t]{3}{*}{ End of $\mathrm{RT} \rightarrow$} & 6 & 770 \\
\hline & 7 & 600 \\
\hline & 8 & 480 \\
\hline \multirow[t]{2}{*}{ Talc pleurodesis $\rightarrow$} & 9 & 220 \\
\hline & 10 & 360 \\
\hline
\end{tabular}

\section{TABLE 1: Chest Tube Drain Output Over the Time of Admission}

Drainage decreased from end of radiation to date of pleurodesis from $770 \mathrm{~mL} / 24$ hours to $220 \mathrm{~mL} / 24$ hours.

Three weeks following the last fraction of radiation, the patient was started on second-line chemotherapy consisting of a single agent, ibrutinib. Follow-up imaging to assess tumor and chylothorax response was arranged; however, a few days later, the patient presented to a local hospital with an acute coronary syndrome. This was felt to be unrelated to his cancer and cancer treatment. As he decompensated quickly, he was transitioned to supportive measures only and died shortly thereafter.

\section{Discussion}

The case presented herein demonstrates that the administration of abdominal radiotherapy can rapidly relieve chylothorax due to a large retroperitoneal lymphoma. In general, management of chylothorax in the setting of lymphoma can include conservative management, radiation, pleurodesis, pleuroperitoneal shunt, or surgery [2]. Although conservative management includes dietary modifications, such as low-fat diet or total parenteral nutrition, to decrease the 
flow of chyle [3], chylothorax will recur if the underlying cause is not treated. Thoracentesis can be helpful in the initial management of malignant chylothorax for immediate relief of respiratory symptoms. While surgical ligation of the thoracic duct is described as a treatment option for traumatic chylothorax, its use in the setting of malignancy is limited, as many such patients are medically inoperable.

There are two proposed mechanisms by which chyle may accumulate in the pleural cavity in the setting of malignancy. The first is thoracic duct rupture, whereby infiltration of the duct by disease can cause it to become increasingly rigid and more susceptible to rupture. The thoracic duct begins at the cisterna chyli at the level of the first or second lumbar vertebra. It ascends into the posterior mediastinum on the right between the aorta and azygos vein, then crosses the midline between the sixth and fourth thoracic vertebrae, emptying into the venous circulation near the left internal jugular and subclavian veins [4]. When the duct ruptures, chyle leaks first into the mediastinum and then into the pleural space. The second mechanism is excess pressure in the thoracic duct. This may cause a retrograde flow of chyle via the lymphatics of the parietal pleura into the pleural cavity [5]. In general, disruptions below the level of T5-T6 produce right-sided chylothorax, and above this level, disruptions can produce left-sided chylothorax $[4,6]$.

Chylothorax can result in severe complications, including compromised lung function due to intrapleural fluid accumulation. Other effects can include metabolic, nutritional, and hemodynamic derangements due to the loss of proteins, immunoglobulins, lipids, electrolytes, and fluid into the pleural space [7]. Accordingly, a prompt diagnosis of chylothorax is crucial, and this is typically made initially based on physical examination and imaging findings that would suggest a pleural effusion. Subsequent thoracentesis with pleural fluid analysis would yield milky fluid that is exudative, odorless, bacteriostatic, and lymphocyte-predominant [8]. The presence of chylomicrons and a triglyceride level greater than $110 \mathrm{mg} / \mathrm{dl}$ confirm the diagnosis of chylous effusion [9].

There are two mechanisms by which radiotherapy can treat chylothorax. Firstly, radiotherapy can shrink gross disease, which can be dramatic and rapid in the setting of radiosensitive cancers, resulting in a relief of pressure on the thoracic duct. Secondly, treatment with radiation may induce an inflammatory response that can result in obliteration of the disrupted thoracic duct, thereby allowing the duct to seal [10].

To complement the case reported herein, we conducted a comprehensive review of the literature evaluating the role of radiotherapy in the treatment of chylothorax caused by malignancy. Using the PubMed database, the following search strategy was completed in July 2016: (chyle leak[tw] OR chylothorax[tw] OR chylothorax[mh]) AND (radiotherapy[mh] OR radiation therapy[tw] OR radiotherapy[tw] OR irradiation[tw] OR radiosurgery[mh] OR stereotactic[tw] OR radiation[tw]). This identified a total of 118 articles. Two clinicians (JML, AVL) reviewed these articles and identified 12 relevant articles, all case reports, examining the role of external beam radiotherapy in the treatment of malignant chylothorax (Table 2).

\begin{tabular}{|l|l|l|l|l|l|}
\hline Study & $\begin{array}{l}\text { Age } \\
(\mathbf{s e x})\end{array}$ & Diagnosis & Effusion & $\begin{array}{l}\text { Radiotherapy } \\
\text { Dose } \\
\text { fractions) }\end{array}$ \\
\hline Ampil $[11]$ & $74 \mathrm{~F}$ & CLL & Left & $\begin{array}{l}1,000 \text { cGy in } 5 \# \text { to } \\
\text { the mediastinum }\end{array}$ & Outcome \\
\hline
\end{tabular}




\section{Cureus}

\begin{tabular}{|c|c|c|c|c|c|}
\hline [12] & $58 \mathrm{M}$ & $\begin{array}{l}\text { retroperitoneum, } \\
\text { mediastinum, HN }\end{array}$ & Bilateral & 3,000 cGy in $10 \#$ & radiation was not completed \\
\hline Daly [13] & $42 \mathrm{M}$ & $\begin{array}{l}\text { Stage IV NHL, mediastinal } \\
\text { mass }\end{array}$ & Left & 3,000 cGy in $10 \#$ & $\begin{array}{l}\text { Resolution after } 6 \text { fractions. No re- } \\
\text { accumulation at } 3 \text { months. }\end{array}$ \\
\hline $\begin{array}{l}\text { Gerstein } \\
{[10]}\end{array}$ & $45 \mathrm{~F}$ & $\begin{array}{l}\text { Stage IVA follicular } \\
\text { lymphoma, celiac trunk }\end{array}$ & $\begin{array}{l}\text { Bilateral } \\
\text { Right > } \\
\text { Left }\end{array}$ & $\begin{array}{l}1,500 \text { cGy in } 10 \# \\
\text { with a boost of } 540 \\
\text { cGy in } 3 \#\end{array}$ & $\begin{array}{l}\text { Improvement after } 5 \text { fractions; } \\
\text { resolution at the end of } \\
\text { radiotherapy. No re-accumulation at } \\
16 \text { months. }\end{array}$ \\
\hline $\begin{array}{l}\text { Heaton } \\
{[14]}\end{array}$ & $70 \mathrm{~F}$ & $\begin{array}{l}\text { Anaplastic carcinoma, } \\
\text { mediastinum }\end{array}$ & Right & 4,000 cGy & $\begin{array}{l}\text { Resolution at the end of } \\
\text { radiotherapy. No re-accumulation } \\
\text { at } 2.5 \text { years. }\end{array}$ \\
\hline $\begin{array}{l}\text { Janjetovic } \\
{[15]}\end{array}$ & $28 \mathrm{M}$ & $\begin{array}{l}\text { Stage IIA HL, mediastinal } \\
\text { mass }\end{array}$ & Left & 3,000 cGy & $\begin{array}{l}\text { Significant regression at the end of } \\
\text { radiotherapy. }\end{array}$ \\
\hline Little [16] & $66 \mathrm{M}$ & $\begin{array}{l}\text { Metastatic prostate } \\
\text { cancer, lungs, } \\
\text { supraclavicular LN }\end{array}$ & Left & $\begin{array}{l}4,400 \text { cGy to the } \\
\text { mediastinum and } \\
\text { left supraclavicular } \\
\text { LN }\end{array}$ & $\begin{array}{l}\text { Resolved and controlled at } 5 \\
\text { months. }\end{array}$ \\
\hline $\begin{array}{l}\text { Scholz } \\
{[17]}\end{array}$ & $65 \mathrm{M}$ & CLL & Right & $\begin{array}{l}2,400 \text { cGy to } \\
\text { the mediastinum } \\
\text { and thoracic duct }\end{array}$ & Persisted at 8 weeks. \\
\hline \multirow{2}{*}{$\begin{array}{l}\text { Swenson } \\
{[18]}\end{array}$} & $28 \mathrm{M}$ & $\begin{array}{l}\text { Lymphosarcoma, } \\
\text { abdomen }\end{array}$ & Bilateral & 3,150 rads in $25 \#$ & $\begin{array}{l}\text { Resolution at the end of } \\
\text { radiotherapy }\end{array}$ \\
\hline & $48 \mathrm{M}$ & $\begin{array}{l}\text { Lymphosarcoma, } \\
\text { abdomen }\end{array}$ & Left & 3,850 rads in $25 \#$ & $\begin{array}{l}\text { Resolution mid-way through } \\
\text { radiotherapy. No re-accumulation at } \\
3 \text { months }\end{array}$ \\
\hline Tan [19] & $53 \mathrm{M}$ & $\begin{array}{l}\text { Stage IV NHL with } \\
\text { concurrent tuberculosis }\end{array}$ & Bilateral & $\begin{array}{l}\text { Mediastinal } \\
\text { radiation }\end{array}$ & Persisted for 57 days \\
\hline $\begin{array}{l}\text { Van De } \\
\text { Voorde } \\
\text { [20] }\end{array}$ & $63 \mathrm{~F}$ & $\begin{array}{l}\text { Stage IIE follicular } \\
\text { lymphoma, celiac trunk }\end{array}$ & Right & 400 cGy in 2\# & $\begin{array}{l}\text { Resolution at the end of } \\
\text { radiotherapy. No re-accumulation at } \\
6 \text { months }\end{array}$ \\
\hline $\begin{array}{l}\text { Zimhony } \\
\text { [21] }\end{array}$ & $81 \mathrm{~F}$ & CLL & Left & $\begin{array}{l}2,100 \text { cGy to the } \\
\text { mediastinum }\end{array}$ & Persisted \\
\hline
\end{tabular}

\section{TABLE 2: Published Case Reports of Radiotherapy for the Treatment of Chylothorax Secondary to Malignancy}

CLL = chronic lymphocytic leukemia; HL = Hodgkin's lymphoma; HN = head and neck; $L N=$ lymph node; NHL = non-Hodgkin's lymphoma 
to TB [19] and another did not complete the course of radiotherapy due to functional decline [12]. Ten of the twelve cases described chylothorax associated with a hematologic malignancy, with nine of these describing a response to radiotherapy.

The dose of radiotherapy delivered was described in 11 of the 12 reports and ranged from 400 cGy in two fractions for low-grade lymphoma [20] to 4,400 cGy for metastatic prostate cancer [16]. The patient presented in the current report was treated with a dose of 2,000 cGy delivered over five fractions. This radiotherapy dose was selected because of concern that treatment with a lower dose would require retreatment in the future. In a randomized Phase 3 non-inferiority trial by Hoskin, et al. [22], a dose of 4 Gy in two fractions was compared to a dose of 24 Gy in 10 fractions in the treatment of low-grade lymphoma. Four Gy in two fractions was inferior with regards to local progression-free survival in both the radical and palliative setting.

Talc pleurodesis following radiotherapy was an important part of the management of chylothorax in the patient presented. In a case series of 19 patients with lymphoma-related chylothorax, medical thorascopic talc pleurodesis was found to have an acceptable complication rate and a $100 \%$ success rate in preventing recurrent pleural effusions [23]. However, the success of talc pleurodesis requires adequate drainage of pleural fluid prior to instillation to ensure apposition of the pleural surfaces. Our patient was initially felt not to be a candidate for talc pleurodesis due to the large volume of pleural fluid. However, with the rapid decline in pleural fluid following radiotherapy, the patient was able to proceed to talc pleurodesis.

\section{Conclusions}

We present a case with significant improvement of chylothorax after 2,000 cGy of radiotherapy. While the follow-up period was limited due to death from a competing risk, the dramatic response of the chylothorax is consistent with results from other published case reports. Furthermore, the initial reduction in pleural fluid accumulation with radiotherapy allowed the patient to undergo talc pleurodesis, which has been shown to be effective in preventing recurrent chylothorax. Due to the high radiosensitivity of lymphomas, radiotherapy should be considered in the management of chylothorax secondary to lymphoma, especially when unresponsive to chemotherapy.

\section{Additional Information}

\section{Disclosures}

Human subjects: Consent was obtained by all participants in this study. Conflicts of interest: In compliance with the ICMJE uniform disclosure form, all authors declare the following: Payment/services info: All authors have declared that no financial support was received from any organization for the submitted work. Financial relationships: All authors have declared that they have no financial relationships at present or within the previous three years with any organizations that might have an interest in the submitted work. Other relationships: All authors have declared that there are no other relationships or activities that could appear to have influenced the submitted work.

\section{References}

1. McGrath EE, Blades Z, Anderson PB: Chylothorax: Aetiology, diagnosis and therapeutic options. Respir Med. 2010, 104:1-8. 10.1016/j.rmed.2009.08.010

2. Nair SK, Petko M, Hayward MP: Aetiology and management of chylothorax in adults . Eur J Cardiothorac Surg. 2007, 32:362-69. 10.1016/j.ejcts.2007.04.024

3. Sriram K, Meguid RA, Meguid MM: Nutritional support in adults with chyle leaks . Nutrition. 2016, 32:281-86. 10.1016/j.nut.2015.08.002 
4. Valentine VG, Raffin TA: The management of chylothorax . Chest. 1992, 102:586-91. 10.1378/chest.102.2.586

5. O'Callaghan AM, Mead GM: Chylothorax in lymphoma: Mechanisms and management. Ann Oncol. 1995, 6:603-607. 10.1007/978-94-011-5456-7_12

6. Doerr CH, Allen MS, Nichols FC 3rd, Ryu JH: Etiology of chylothorax in 203 patients . Mayo Clin Proc. 2005, 80:867-70. 10.4065/80.7.867

7. Jimenez CA, Mhatre AD, Martinez CH, Eapen GA, Onn A, Morice RC: Use of an indwelling pleural catheter for the management of recurrent chylothorax in patients with cancer. Chest. 2007, 132:1584-90. 10.1378/chest.06-2141

8. Connolly JE, Smith JW: The management of chylothorax. Calif Med. 1959, 91:75-78.

9. Romero S: Nontraumatic chylothorax. Curr Opin Pulm Med. 2000, 6:287-291.

10. Gerstein J, Kofahl-Krause D, Frühauf J, Bremer M: Complete remission of a lymphomaassociated chylothorax by radiotherapy of the celiac trunk and thoracic duct. Strahlenther Onkol. 2008, 184:484-87. 10.1007/s00066-008-1840-4

11. Ampil FL, Burton GV, Hardjasudarma M, Stogner SW: Chylous effusion complicating chronic lymphocytic leukemia. Leuk Lymphoma. 1993, 10:507-10. 10.3109/10428199309148211

12. Cigarral C, Montero A, Salas C, Rodríguez G, de la Torre A: Chylothorax due to metastatic prostate carcinoma: an unusual complication. Clin Transl Oncol. 2009, 11:767-69. 10.1007/s12094-009-0441-8

13. Daly MM, Kunkler IH: Chylothorax in non-hodgkin's lymphoma managed by mediastinal radiotherapy. Clin Oncol (R Coll Radiol). 1995, 7:397-99. 10.1016/S0936-6555(05)80015-9

14. Heaton RW, Arnold IR, Howard N, Guz A: Successful treatment of chylothorax and superior vena cava obstruction by radiotherapy. Thorax. 1987, 42:153-54. 10.1136/thx.42.2.153

15. Janjetovic S, Janning M, Daukeva L, Bokemeyer C, Fiedler W: Chylothorax in a patient with Hodgkin's lymphoma: a case report and review of the literature. Tumori. 2013, 99:e96-9. 10.1700/1334.14813

16. Little NA, Walther PJ: Chylothorax: a rare complication of metastatic prostatic carcinoma . J Urol. 1985, 134:1215-17.

17. Scholz GA, Sirbu H, Semrau S, Anders K, Mackensen A, Spriewald BM: Persisting right-sided chylothorax in a patient with chronic lymphocytic leukemia: a case report. J Med Case Rep. 2011, 5:492. 10.1186/1752-1947-5-492

18. Swenson NL, Kurohara SS, George FW 3rd: Complete regression, following abdominal irradiation alone, of chylothorax complicating lymphosarcoma with ascites. Radiology. 1966, 87:635-40. 10.1148/87.4.635

19. Tan KL, Lim LC, Hsu AA, Eng P, Ong YY: Chylothorax: case report and review of the literature. Ann Acad Med Signapore. 1997, 26:225-28. 10.1016/S0736-4679(02)00751-5

20. Van De Voorde L, Vanneste B, Borger J, Troost EG, Werner P: Rapid decline of follicular lymphoma-associated chylothorax after low dose radiotherapy to retroperitoneal lymphoma localization. Case Rep Hematol. 2014, 2014:684689. 10.1155/2014/684689

21. Zimhony O, Davidovitch Y, Shtalrid M: Chronic lymphocytic leukaemia complicated by chylothorax. J Intern Med. 1994, 235:375-77. 10.1111/j.1365-2796.1994.tb01090.x

22. Hoskin PJ, Kirkwood AA, Popova B, Smith P, Robinson M, Gallop-Evans E, Coltart S, Illidge T, Madhavan K, Brammer C, Diez P, Jack A, Syndikus I: 4 Gy versus 24 Gy radiotherapy for patients with indolent lymphoma (FORT): a randomised phase 3 non-inferiority trial. Lancet Oncol. 2014, 15:457-63. 10.1016/S1470-2045(14)70036-1

23. Mares DC, Mathur PN: Medical thoracoscopic talc pleurodesis for chylothorax due to lymphoma: a case series. Chest. 1998, 114:731-35. 10.1378/chest.114.3.731 